\title{
Journal prices lead fibraries to back less costly initiatives
}

[WASHINGTON] A coalition of North American university libraries is planning to launch a bid next week to reduce the power of commercial scholarly publishers by endorsing new publishing ventures that it considers give value for money.

The initiative is being launched by the Scholarly Publishing and Academic Resources Coalition (SPARC), a body set up last October by the Association of Research Libraries (ARL). The first in a series of partnership agreements with journal publishers is due to be unveiled next Tuesday at the annual conference of the American Library Association in Washington, DC.

Under such agreements, publishers will undertake to launch high-quality, low-priced journals in fields that are currently dominated by expensive titles. In return, SPARC will guarantee a subscription base of research libraries, and help to generate support for the new journals from faculty, learned societies and educational organizations.

The SPARC project reflects a growing concern among the coalition's members, which include prominent research universities such as Harvard University, the University of California at Los Angeles and the University of Toronto, about the rapidly increasing cost of library materials, especially research journals.

Last year, ARL estimated that, despite having cancelled hundreds of thousands of dollars' worth of subscriptions, research libraries were still spending 124 per cent more than they had in 1986, in order to acquire 7 per cent fewer titles. Between 1986 and 1996, the cost of scholarly journals increased by 148 per cent - far outpacing growth in both the consumer price index ( 44

\section{'Insider' gets energy secretary nomination}

[WASHINGTON] President Bill Clinton last week nominated Bill Richardson, the US ambassador to the United Nations and a former congressman from New Mexico, as the next energy secretary. The 50-year-old Richardson is a Clinton friend, a Democratic insider and, like outgoing energy secretary Federico Peña, a Hispanic.

He is also well acquainted with the department he is to head. From 1983 to 1997, he represented the congressional district that includes two key Department of Energy (DOE) labs, Sandia and Los Alamos, which he helped to protect from budget cuts as a member of the House commerce committee.

New Mexico's interests are likely to remain crucial to DOE politics if Richardson's appointment is confirmed. He is thought to have his eye on governorship of that state, or perhaps a role as Al Gore's running mate in the next presidential race. Pete Domenici, New Mexico's Republican Senator, already chairs the appropriations panel that determines the DOE's budget.

Richardson brings to his new job a strong interest in international affairs. Even before his move to the UN, Clinton used him in hostage negotiations with several countries, including Cuba, Iraq and North Korea. He has twice been nominated for the Nobel peace prize.

In a White House ceremony to announce his nomination, he mentioned the value of technical advances for environmental cleanup and energy research. He also spoke of the need to maintain a safe and reliable

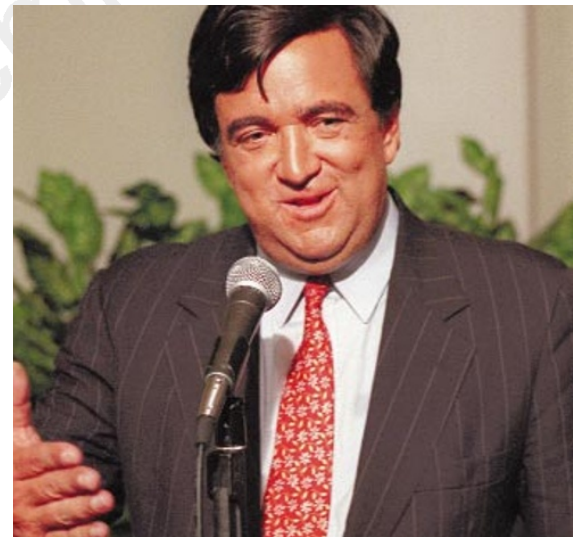

Richardson: expected to be confirmed in post, but may face some embarrassing questions

nuclear stockpile to better support the Comprehensive Test Ban Treaty.

In Congress in the early 1990s, Richardson was sharply critical of DOE plans for the Waste Isolation Pilot Plant, the controversial underground nuclear waste repository in his home state, and he worked to ensure stringent environmental standards for the project. Ironically, he is likely to preside over the plant's early operations (see Nature 393, 199; 1998).

Richardson's nomination is not likely to meet resistance in the Senate, which has to confirm the appointment. But he may face embarrassing questions about his minor role in the scandal involving former White House intern Monica Lewinsky, whom he offered a job at the UN last year. Tony Reichhardt per cent) and university operating budgets.

Mary Case, director of ARL's office of scholarly communication, says SPARC intends "to develop prestigious, cost-effective alternatives" to existing journals. "The aim is to lure faculty, publishers and editors away from high-priced titles," she says.

Eighty of ARL's 121 members are founding members of SPARC, and have each contributed $\$ 5,000$ to a start-up fund for the project. SPARC will not publish journals itself, but will enter into partnerships with publishers that share its aims.

According to Case, these encompass not just lower cost, but "access under terms that include educational uses and fair use - for example, giving [publication] rights back to the author". (Demand for the latter has increased significantly with the advent of personal Web sites and public 'e-print' servers.)

The first publisher to sign up with SPARC will be the American Chemical Society (ACS), which already publishes 26 journals in print and electronic form. ACS is planning to announce next week what it hopes will be the first of a number of new journals launched under the agreement with SPARC. "They can assist us to do what we want to do anyway expand our line of publications," says ACS's publications director, Bob Bovenschulte.

SPARC's assistance in this case will be non-financial; according to Bovenschulte, they will merely endorse the new publication, and "help to sell subscriptions" - for example, by educating faculty and university administrators about the need to reduce the costs of scholarly communication. Looking ahead, Bovenschulte says that ACS hopes to launch at least one new journal a year in partnership with SPARC.

Bovenschulte believes that in general and unlike commercial publishers - professional societies have not been as responsive as they might have been in launching new publications as new sub-fields of established disciplines have emerged.

"We've all ceded a lot of ground to commercial publishing houses who have been more aggressive and had a lot of investment capital," he says. "We haven't been starting new publications with risk capital."

Case emphasizes that SPARC is not seeking to compete with all commercial publishers, but only to challenge those it considers impose unfair profit margins or excessively restrictive copyright policies. "I envisage that we would [work jointly] with both commercial and non-commercial publishers," she says. "We're looking for partners who share ourvalues."

LauraGarwin 